CATALAN REVIEW

Catalan Review

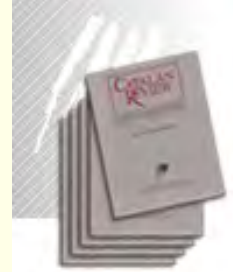

You are accessing the Digital Archive of the Catalan Review Journal.

By accessing and/or using this Digital Archive, you accept and agree to abide by the Terms and Conditions of Use available at http://www.nacs-

catalanstudies.org/catalan review.html

Catalan Review is the premier international scholarly journal devoted to all aspects of Catalan culture. By Catalan culture is understood all manifestations of intellectual and artistic life produced in the Catalan language or in the geographical areas where Catalan is spoken. Catalan Review has been in publication since 1986 .
NORTH

AMERICAN

CATALAN

SOCIETY
Esteu accedint a l'Arxiu Digital del Catalan Review

A l' accedir i / o utilitzar aquest Arxiu Digital, vostè accepta i es compromet a complir els termes i condicions d'ús disponibles a http://www.nacs-

catalanstudies.org/catalan review.html

Catalan Review és la primera revista internacional dedicada a tots els aspectes de la cultura catalana. Per la cultura catalana s'entén totes les manifestacions de la vida intel lectual i artística produïda en llengua catalana o en les zones geogràfiques on es parla català. Catalan Review es publica des de 1986.

\title{
Cultural Capital: The Play of Language, Gender, and Nationality in Carme Riera Maryellen Bieder
}

Catalan Review, Vol. XIV, number 1-2, (2000), p. 53-74 


\title{
CULTURAL CAPITAL: THE PLAY OF LANGUAGE, GENDER, AND NATIONALITY IN CARME RIERA
}

\author{
MARYELLEN BIEDER
}

Carme Riera's penchant for exploiting the seductive potential of narrative has drawn much critical commentary, especially as regards her play of gender in such works as "Te deix, amor, la mar com a penyora" ["I Leave You, My Love, the Sea as a Token"] and "Jo pos per testimoni les gavines" [I Call on the Seagulls as Witness], where she seduces her reader into misreading gender. ${ }^{1}$ Riera herself has spoken often about the importance of narrative seduction in maintaining the reader's interest (Glenn, "Conversation" 207; Aguado 35-36). In many of her stories this seduction doubles - or even triples: Riera's seduction of her reader mirrors the narrator's seduction of the narratee and replicates one character's seduction of another. Turning to some less-studied narratives in which she also manipulates the reading of gender, I want to explore how she interweaves the question of national identity into her play of gender and language. A recent critic cites Riera among the writers she identifies as engaging in "reconstructing and reconfiguring Catalan national identity" (Vilarós 38). More specifically, Noël Valis, in an illuminating discussion of "intertextual/ intersexual specularity" (318), recognizes that the implications of Riera's "critique of the institutions and institutionalization of writing itself and authorship in late twentieth-century Spain" require further study (3I6). As Valis reminds us, "Almost all the stories in Contra l'amor en companyia [Against Love with a Partner and Other Tales] deal with literature, writing and writers, and rivalries between writers, often in humorous or ironic-parodic fashion. The institutions of authorship and writing are targeted here," as they are, she continues, in Qüestió d'amor propi [A Question of Self-Love] (3I4). Implicit in Valis's discussion of authorship, writing and sexuality is the question of national identity.

"The promotion of Catalan culture," affirms Antonio Elorza, "is inseparable both from the politics of 'linguistic normalization," undertaken by the authorities, and from the discourse of political nationalism" (343). He defines the project of "cultural normalization" in the following terms:

I Akiko Tsuchiya was one of the first critics to elaborate on Riera's conscious manipulation of the layers of seduction within her texts and between readers and the text. 
the institutionalization of Catalan culture and the construction of cultural infrastructures, the consolidation of a media industry in Catalan, and the extension of habits of cultural consumption in the Catalan language. The final goal of this project is to read a situation of de facto cultural independence" (343).

In regard to the importance in language in the project of nationhood, the Encyclopedia of Spanish Culture states the obvious: "Throughout the twentieth century language has been central to discussions about national and regional identity in Spain" (Stewart 293). Writing in Nations Against the State, Michael Keating addresses more specifically the role of intellectuals and artists in nation-building: "Cultural activities may or may not be explicitly political or make reference to identity and nationalism. Even where they do not, they continue to shape national identity by framing the issues and interpreting daily life" (9). As for the ever-thorny dilemma of whether to refer to the Spanish language as español or castellano, the article concedes: "That this and other language-related issues have the power to inflame passions and ensure a constant stream of letters to the editor' in the Spanish press testifies to the importance of language to notions of national identity in contemporary Spain." In commenting on the suppression of the Catalan language in post-Civil War Catalunya, Montserrat Roig terms the situation "esquizofrénico" [schizophrenic] (Nichols 152). ${ }^{2}$ In contrast, a leading Barcelona publisher recently referred proudly to "la cotidianidad con que conviven castellano y catalán" [the ease with which Castilian and Catalan coexist] in the city, asserting that linguistic differences "a menudo sólo son ruido de fondo" [often are only so much background noise] (qtd. in Mérida-Jiménez I47). Riera takes the opposite tack, foregrounding in some of her fiction the tensions inherent in writing in Catalan in a Spanish-speaking country. In these works she figures the dark side of the clash between national languages as a kind of linguistic and cultural schizophrenia, as she explores the contemporary dynamics of national identity in Spain. At the same time through her dramatization of the interplay of language(s) and cultural institutions she satirizes the

2. Roig is using a well-established trope. Manuel Vázquez Montalbân has declared that in Spain in the ig Gos "[v]iviamos esquizofrénicamente" [we lived schizophrenically], halfway between the Francoist ideal and a democratic ideal (82, see also 89). Recalling Barcelona, he affirms: "Desde Barcelona se asistía desde la platea al espectáculo de la esquizofrenia de una sociedad que durante seis días debía someterse a las verdades oficiales y el séptimo día cogía el coche para irse a Perpiñán a ver... El último tango en Paris" [In Barcelona one had ground floor seats for the spectacle of the schizophrenia of a society that for six days had to submit to official truths and the seventh day took the car and went to Perpignan to see... "The Last Tango in Paris"] (82). I follow Roig in using schizophrenia to refer more specifically to the tension between the use of the Castilian and Catalan languages. 
commodification of culture - culture as capital in both Catalunya and Spain $^{3}$

Jo Labanyi has warned that "the current use of culture to manufacture forms of regional identity comes close to replicating its manipulation by early Francoism to fabricate 'an essentially different Spanishness' (403). The "regional appropriation of postmodernism to expose the constructed nature of all identities," she concludes, "offers a way out of the trap of essentialism." It is my contention that much of Riera's fiction puts into play the constructedness not only of Catalan nationality but of language, gender and culture.

As is well known, Riera's own fictional practice embraces writing in both Catalan and Spanish. She has penned Spanish versions of most of her Catalan narratives novels and short stories. In this way she writes and rewrites her fictions, mediating between languages. In her 1989 novel Joc de miralls [Mirror Images], for example, she dramatizes through her narrator/protagonist the fatal desire to decipher the identity of a writer: his personality, his language, his texts, his personal history, his physical characteristics. This fascination with the intersection between writing and the author's cultural formation lies at the heart of her fiction.

Riera's childhood in Mallorca, the language politics of the Franco era, and her experience as a university professor, mark her relationship to language and to literature. Both as a literary critic and as a writer of fiction, she is not surprisingly self-conscious in her use of language and in representing the role language plays in cultural production. In contemporary Spain, the act of writing in Catalan no longer carries the same connotations - and perhaps the force of resistence - that it did under Franco. In a number of her fictions Riera deconstructs language both as a cultural gesture and as the defining characteristic of nationality, dramatizing the consequence for her characters of writing and publishing in Catalan. In her own career, she interweaves writing fiction with the translation of her own works into Spanish. Her translations-cum-variations of such works as Joc de miralls, retitled Por persona interpuesta [Via An Intermediary] in her Spanish version, and "Pos per testimoni les gavines," consequently differ considerably from more literal commercial translations. In a brilliant deconstructive reading of Qüestió d'amor propi, Brad Epps offers examples of how Riera's Spanish text changes the register of the original Catalan (I46, n. I). In

3 In my use of the concept of cultural capital, I am taking Bourdieu's discussion of the "relationships between groups maintaining different, and even antagonistic, relations to culture, depending on the conditions in which they acquired their cultural capital and the markets in which they can derive most profit from it ${ }^{3}$ (12) and extending it to apply to the national cultural industries of Spain and Catalunya. 
effect, under the guise of translation Riera writes fiction in Spanish, the language she also uses in her academic writing;

I write in Catalan but I teach Spanish literature and I'm completely bilingual. When I translate something I have written, I often find that the text does not "work" in Spanish and so rather than translate I write a new version. Por persona interpuesta, for instance, is not exactly the same as the Catalan original, Joc de miralls. (Glenn, "Conversation" 209)

As one of her characters remarks about his translation of his friend's poetry: " $\mathrm{i}$ fins i tot, en algun vers, m'havia permès millorar l'original" [in some verses I even allowed myself to improve on the original] (Contra l' amor 53). Riera's receipt of the Premio Nacional de Narrativa attests to the fact that she has won recognition as a "Spanish author," a transcendence of cultural boundaries that the characters in her fiction do not always achieve.

Riera's linguistic history is, not surprisingly, complex. Responding to a question about whether she spoke Mallorcan at home, she explained:

No, hablaba las dos lenguas; las muchachas que atendían la casa eran emigrantes de Murcia, y hablábamos castellano con ellas. Mis padres hablaban con nosotros mallorquín, pero entre ellos hablaban castellano, porque al ser mi madre catalana de Barcelona, y mi padre mallorquín, no se comprendieron al principio bien. ¿Tú sabes que los catalanes no entienden a los mallorquines?... Empezaron a hablar en castellano ellos, $y$ han seguido hablando en castellano toda la vida. De modo que mi situación de bilingüismo es total. (Nichols 195) ${ }^{4}$

[No, I spoke the two languages; the housemaids were immigrants from Murcia, and we spoke Spanish with them. My parents spoke to us in Mallorcan, but between themselves they spoke Spanish, because since my mother is a Catalan from Barcelona, and my father a Mallorcan, they did not understand each other well at first. Do you know that the Catalans do not understand the Mallorcans? ... They began to speak to each other in Spanish, and they have continued speaking in Spanish all their lives. With the result that my situation is one of total bilingualism.]

Thus for Riera not only Spanish and Catalan but normative Catalan and the Mallorcan dialect complicate the matter of linguistic identity. Speaking of her literary formation, Riera has remarked that "Es muy curioso porque es eminentemente castellana, puesto que yo vengo a estudiar a Barcelona" [It's very strange because it's eminently Spanish, since I came to Barcelona to study]" (Nichols 187). She also posits a kind of linguistic determinism that underlies her decision to write fiction in Catalan: 
yo creo que todas las lenguas sirven para hablar; otra cosa es la lengua en la que escribes. En realidad, tú no escoges esta lengua, sino que te escoge a ti, porque no te podrías expresar más que en la lengua de tus vivencias íntimas... en este sentido escoge a ti. (Nichols 198)

[I think that all languages are good for speaking, but the language in which you write is another matter. In truth, you don't choose this language; it chooses you, because you could not express yourself in any other language than the language of your intimate experiences... . in this sense it picks you.]

As Noël Valis observes in another context, Riera's attitude "has its roots in the romantic model of the writer as embodying the creative realization of one's self" (320).

In her self-awareness of language as personal history, Riera draws attention throughout her fiction to the interplay between language and national identity. The texts I have selected are each in their own way a linguistic tour de force that probes the boundaries of gender, culture and language. The first interrogates culture only tangentially, while the second figures the linguistic and cultural divide in terms of gender; the last brings all these facets together to confront cultural schizophrenia head on. ${ }^{5}$ y focus lies on the effects of the characters' selfconsciousness about language and on Riera's toying with reader expectations and assumptions to critique cultural institutions. One of Riera's less familiar stories, "Joc de cartes" [Card Game] from the collection Contra l'amor en companyia, suspends gender identification and highlights language. ${ }^{6}$ Here the gender of the protagonist is unmarked, as is the gender of the person on whose life and recent death the protagonist fixates. This doubled gender ambiguity is enhanced by the use of third-person narration and the suppression of gender-marked pronouns and adjectives. Since the protagonist possesses a collection of love letters written by a famous literary personage who has just died, the conventional reading seems to suggests a female protagonist. Historically, literary fame is the province of men, but contradictory clues point to opposing gender readings. The description of the letters themselves, however, gestures only towards a virginal sanctity:

Les seves cartes, plegades en tríptic, ja no conservaven cap empremta de l'antic perfum... En canvi, [el paper] mostrava el mateix blanc impol.lut en el qual

5 I do not treat these texts in the order in which Riera wrote them. The stories from Contra l'amor en companyia carry the date 1989 , two years after the publication of Riera's novel Qüestió d'amor propi (1987).

6 The collection Contra el amor en compañia, published by Destino, gives no indication that the volume is a translation, no indication of the mediating hand of a translator; furthermore, the Spanish translation appears to have been published simultaneously with the Cacalan original. 
destacava el segell de la Real Academia i el nom de la seva honorable persona. (Contra 10g)

[The letters, folded in thirds, no longer held any trace of their former perfume,... In contrast, the paper displayed the same unpolluted whiteness against which the letterhead of the Real Academia and the name of the honorable member stood out.]

By specifying that the letters, dated $1988-1989$ (and hence contemporaneous with Riera's writing of the story), were composed some 30 years prior to the narrative present, the story imposes a temporal framework that extends three decades into the reader's future and shifts the horizon of cultural expectations. ${ }^{7}$ The fact of election to the Real Academia, the Spanish Royal Academy of Language, seems to resolve the gender indeterminacy by confirming that the "honorable person" is a man. Throughout most of its history the Real Academia has been an exclusively male institution. The memory of the frustrated candidacies of two prominent women authors Gertrudis Gómez de Avellaneda and Emilia Pardo Bazán, serves as a reminder that the Royal Academy did not admit its first woman until the election of Carmen Conde in 1978.

The plot of Riera's story turns on the business of fame: an attempt by the protagonist to cash in on a collection of love letters, rather like collecting on an insurance policy in old age. ${ }^{8}$ Riera pokes fun the commercial side of fame - fame as cultural capital - and the valuation of the literary relics of a newly dead author. Her language parodies the almost religious veneration accorded the Real Academia and the infallibility of its edicts, not excluding, in this case, vulgar love letters inscribed on its letterhead: "Posades sota l'advocació de la Institució, com si fos una santa patrona o una verge miraculosa, les seves paraules tenien una doble garantia de fermesa" [Placed under the protection of the Institution, as though it were a patron saint or a miraculous virgin, ${ }^{9}$ the letter writer's words had a double guarantee of reliability] (IIo). The joke is on the protagonist, however: other recipients received

7 The protagonist emphasizes the temporal distance with reference to the Real Academic letterhead: "aquest fet que fou decisiu trenta anys enrera continuava tenint encara una gran importància, però ara jugava a favor seu" [that fact which was decisive thirt y years earlier, still had great importance, but now it favored in the protagonist] (109). The protagonist has naively taken the august stationery as a sign of the sender's seriousness.

8 In an interview Riera mentioned the high price that the letters of the rich and famous fetch, "vendiéndolas a un banco como hicieron con las de aquella señora que había sido novia de Pablo Neruda" [selling them to a bank, as they did with those of that woman who had been a girlfriend of Pablo Neruda] (Nichols 226).

9 In her Spanish translation, Riera inserts the comparison "ángel tutelar" [guardian angel] (Contra el amor no) between the other two. 
the same love letters accompanied by the same personalized poems: "només es variava el nom del destinatari, malgrat que aquesta variació tot sovint donés peu a un vers coix o sobrat de sillabes" [only the name of the recipient varied, despite the fact that that variation often gave rise to a broken line or too many syllables] (II3). The larger joke, nevertheless, is on the reader. When Riera resolves the gender confusion by identifying the letter writer as a woman, "la tercera dona que havia entrat a la Real Academia de la Lengua pels seus propis mèrits" [the third woman to have entered the Royal Academy of Language on her own merits] (Ii4), the protagonist's gender comes firmly into focus as male. Riera's Spanish translation shifts the emphasis slightly to clarify that the woman was a candidate "con méritos sobrados" (II4) [with more than sufficient merit] (Contra el amor II4).

Consequently, the entire story stages a gender reversal: a famous woman writes letters on the stationery of an eminent - and eminently male - institution to her many lovers. Riera inverts both the image of a don Juan academician, with his multiple conquests and paper trail of letters, and the image of the vengeful and embittered abandoned woman. By having the letters written on official stationery in 19881989, Riera is rewriting institutional history, giving the Real Academia the history its members rejected by inventing two additional women members. What Riera's game of hide-and-seek puts into play here are cultural assumptions, not only about a Spanish institution, but about gender relations, the symbolic value of writing and the economy of fame. Her story grants women parity with men as sexual predators and as cultural commodities. Because Riera writes in Catalan, nationality also factors into the story. Although it is only marginally implicated in the original Catalan version, it is absent completely from Riera's Spanish translation. By suppressing the protagonist's name, "senyor Mas" (II4), in the translation, Riera also suppresses the protagonist's Catalan identity and eliminates the element of cultural tension. In Catalan, the story implicitly draws attention to the marginal position of the Catalan language and culture within Spain, as symbolized by its premier cultural institution. It also suggests, perhaps, the Catalan protagonist's excessive awe and admiration, expressed as we have seen as an almost religious veneration, for the stuffy Real Academia. In some sense, then, the story plays out Spain's cultural hegemony in its gender-role reversal of the dominant woman and the Catalan male's concomitant sense of humiliated victimization. Regardless of its muted treatment of national identity, in both versions the institutionalization and commodification of culture remain prime targets of Riera's satire.

With the male protagonist's gender at last grammatically confirmed, the story reinscribes gender stereotypes in his closing 
diatribe against his former lover: "'La gata maula,' pensà, 'fins i tot després de morta continua comandant" "The bitch, he thought, even after she dies she's still in charge] (II4). There is one final gender reversal, however, in which the male protagonist is glimpsed a final time, crying "com la primera vidua" [like the official widow] (II5). The letter writer may have been an old tart, but the male weeping widowprotagonist is equally stereotyped as exploiting a one-time sentimental attachment to a cultural icon. Fame, Riera seems to say, reduces all emotions to cash.

One of Riera's most admired works, Qüestió d'amor propi, translated by her into Spanish as the flyleaf stipulates, more fully fleshes out the interdependence of writing and national identity. The novel's epistolary first-person narrator, Angela Caminals, is a Catalan writer and author of the novel Interior amb figures [Interior with Figures] who lives in Barcelona. At a writers' conference Àngela meets - confronts - Miquel, a Spanish author and "un dels escriptors de moda més ben tractats per la crítica" [one of the fashionable writers that the critics treat best] (Qüestió 29). The encounter between the two in the mediating space of Valencia, the home base of neither character, is both sexual and cultural. Miquel represents literary fashion and critical acclaim; for him, books are a cultural commodity that advance his career. Anngela is a peripheral writer in terms of language, gender, national identity and genre, as the title of her novel attests. She admits that she has nothing to offer Miquel in the way of cultural advancement, economic advantage or sexual prestige: "ni a la meva edat jo sóc cap trofeu digne d'exhibir" [at my age I'm certainly not a trophy worth exhibiting] (38). Miquel represents, quite literally, the Madrid literary establishment; Angela, the marginal world of Catalan literature:

Més aviat era jo qui, en tot cas, m'hagués pogut aprofitar de la bona posició del Miquel al món de la cultura ja que, tot just uns mesos abans de conèixer-nos, l'havien nomenat director de la Fundación Para el Progreso de la Cultura, una de les més importants de l'estat. (38)

Rather it was I who, in any case, could have profited from Miquel's good position in the world of culture since, just a few months before we met, he was named the director of the Foundation for Cultural Progress, one of the most important state foundations.]

Her fiction reaches beyond Catalan culture only in translation, through the work of "[l]a meva traductora al castellà" [my translator into Spanish] (70), a statement that may reflect Riera's discomfort with publication in Spanish. Miquel's verbal seduction of the narrator (who, in turn, is seducing her narratee, as Riera is seducing us, the novel's readers) places her at center stage with Miquel as her audience. As 
Àngela recalls his words, he told her: "que jo era la persona més interessant que havia trobat al congrés, la primera dona que en un debat li havia posat els punts sobre les is $i$, sobretot, que era un entusiasta admirador de la meva obra" [that I was the most interesting person that he had encountered at the conference, the first woman who in a debate had put him in his place, and, above all, that he was an enthusiastic admirer of my work.] (32) Miquel spins his seduction by representing himself in a position of admiring inferiority to Àngela, a position more frequently adopted by woman in the presence of a powerful man. His language empowers her as a woman, an intellectual and a novelist. He obviates their competitive roles as writers in search of an audience, presenting himself as a reader of her fiction, the ultimate compliment for an author.

As their personal contact increases, their language becomes intertwined: "Fins i tot ambdós vam començar una narració en la qual anàvem intercalant paràgrafs como si ens projectéssim en un joc de miralls" [In the end we both began a story in which we each kept on inserting paragraphs as if we were projecting ourselves in a game of mirrors] (36). The joc de miralls is not a gratuitous image here; what each writer sees in the other, and in the other's language, is the self reflected. ${ }^{10}$ As the two authors and their language(s) merge, the Madrid-Barcelona cultural dichotomy seems to collapse. Miquel quotes Ausiàs March in Catalan (34); Angela reciprocates, in a further mirroring, by citing Salinas (36). But when Miquel spins his version of their love affair in his novel El canto del cisne [The Swan Song] (68), the conflict between dominant and subordinate genders and cultures reemerges. (As Brad Epps has already noted, the tension between Ãngela as a Catalan author and Miquel as Spanish writer is lost in the Spanish translation, in which the titles of both Angela's and Miquel's novels are rendered in Spanish [13].) In the sexual relations between Àngela and Miquel, the woman writer feels her private body has been exploited by the public body and dominant language of the male writer. Miquel's appropriation of Àngela's body and her story in his novel figures what, in another context, one critic has identified as the "position of inferiority" that Catalan products occupy due to "the collision of two cultural markets (Spanish versus Catalan) in the same territory" (Elorza 345).

After their brief affair and separation, Angela takes the measure of

Io Epps perceptively expresses the novel's interface of gender and specularity: "Àngela sees Miquel as seeking a mirror, as narcissistically obsessed with finding reflections and replications of himself, as a man, in women." Angela, Epps continues, plays a similar mirroring game with her narratee, Ingrid (144). He has also recognized the frequency with which Riera invokes the "phrase (and concept) joc de miralls" in this novel, as well as making it the title of a previous novel, Joc de miralls (r47, n. 14). 
the distance between her lover and herself in geographical terms: he returns to his job and family in Madrid as if she had never had a place in his life, while she remains in Barcelona (Quiestió 58-59). This emotional, cultural and geographical distance plays out in Miquel's falsely hearty response when she calls him from Barcelona:

-... Però digue'm, ¿a on ets?

-A casa, a Barcelona.

-A Barcelona... Em temo que no podré anar a Barcelona fins d'aquí a uns mesos...

-No et preocupis, Miquel, jo tenc un viatge pendent a Madrid.

¿A Madrid? iEsplèndid! (59-60)

["But tell me, where are you?"

"At home, in Barcelona."

"In Barcelona... I'm afraid I won't be able to go to Barcelona until a couple of months from now."

"Don't worry, Miquel, I have a trip to Madrid planned."

"To Madrid? Splendid!"]

Culturally, Madrid and Barcelona remain two separate worlds, as close as a plane ride and as far apart as their cultures, the irreconcilability of the distance between them neatly satirized in Riera's finely nuanced dialogue. ${ }^{\mathrm{A}}$ A recent article in El País announces: "Autores catalanes establecen un puente cultural con Madrid" [Catalan authors establish a cultural bridge with Madrid] (V.). The Cultural Bridge refers to a conference organized by Catalan writers to discuss "las relaciones socioculturales entre Madrid y Barcelona" (V.) and sponsored, significantly, by the Fundación Caixa Catalunya.

Riera's playfulness goes beyond two competing cultural scenes, two bodies with incompatible gender expectations, and two distinct languages. She suggests that Miquel is a writer that readers know well, and her novel invites her readers, just as Àngela invites her narratee, to identify his last name. Within Angela's narrative Miquel's last name is Orbaneja, but beyond Angela's letter Riera tempts the reader to identify a prominent cultural figure from the Madrid literary scene (80). ${ }^{12}$ Thus here Riera does not suppress identity so much as she supplants it, with the suggestion that we recover the authentic, unfictionalized identity, much as within Qüestió Miquel's novel El canto del cisne is a play of real and fictional identities.

In Riera's allegory of sexual politics as cultural politics, Catalan culture lacks the economic clout and the international prestige of

in Epps comments that "the text flirts self-consciously with national stereotype" in its presentation of both Angela and her Danish friend Ingrid (125).

12 In an act of resistence to Spanish cultural hegemony, Àngela writes Miguel Orbaneja's name only in Catalan -Miquel. 
Spanish culture. Miquel is Spanish culture, as his appointment to head the Foundation for Cultural Progress underscores. ${ }^{13}$ Significantly, Riera names the foundation in Spanish in the original Catalan novel; the name resists translation since the position empowers Miquel precisely because it represents the cultural hegemony of Spanishlanguage Spain. Culture is a growth industry for entrepreneurs like Miquel, for whom literary prestige brings junkets, adoring women and photographic displays in the popular press. Miquel and Àngela's specular gaze and collaborative linguistic creativity degenerate into a cultural power play in which the Catalan writer loses out. Literary culture in Spain dominates from Madrid, from which center it seduces -and abandons- peripheral authors, colonizing them and then moving on to other conquests. ${ }^{14}$ Success in the nation's capital is both a plane ride away from Barcelona and as unlikely as requited love for Ãngela.

The text in which Riera weaves her most complex and ironic web of gender, language and national identity is the story "Mon semblable, mon frère," which forms part of the collection Contra l'amor en companyia.15 The title reproduces the last line of "Au lecteur," Baudelaire's prefatory poem to Les fleurs $d u$ mal. The reference to the French poet sets in motion the story's multiple overlays of intertextuality, while at the same time foregrounding language and shifting the frame of gender conflict to male homosexual desire. As the title suggests, in the story the lives of two men mirror each other in linguistic, artistic and ultimately sexual interdependence. ${ }^{16}$ The narrator and his alter ego are children of the Spanish Republic who enter the university of Barcelona in the mid-1950's, when Spanish is the official language of Catalunya. Riera uses the two to embody opposing histories of language usage in Catalunya, what Geraldine Nichols calls the "política linguística familiar" [family's language politics] ("Mitja poma" II9): one is a Spanish speaker, the other a Catalan speaker. The first-person narrator is from a family that "pertanyia als vencedors i era rica, la qual cosa, si bé em féu sofrir alguns mals de panxa, facilitava

${ }_{13}$ Epps also underscores the significance of Miquel's title being given in Spanish (I3).

14 The metaphor of the colonizing tendency of Madrid culture continues. After leaving Barcelona, Miquel appears a few days later on a Mediterranean cruise.

is In an insightful and delightfully written article, Mirella Servodidio elucidates the story's rich Borgesian web of intertexts spun by what she calls "Riera's electronic story machine" (44I). She identifies the Bonomini and Millas intertexts that frame the story's play of dual identity and literary creation. She also points to the story's "register of ambiguity" in which real authors and fictional names intertwine.

I6 In her study of doubling in Riera's fiction, Catherine Bellver discusses "Mon semblable, mon frere" as a story in which "[t]here seems to exist between the two [men] the element of irresistible, almost fatal attraction and the "certain strange and special affinity' necessary as a basis for a second self $n$ (244). 
molt el meu avenir" [belonged to the winners and was rich, which, if it made me suffer a few pangs of conscience, greatly facilitated my future] (Contra 42). ${ }^{17}$ In contrast, his friend and nemesis, Rafel Recasens, although Catalan, spent his early childhood in France, as the narrator recalls:

a Narbona, on el seus pares s'havien traslladat quan esclatà la guerra, i des d'on tornarien a mitjan dels anys quaranta perquè els seus fills poguessin educar-se en contacte directe amb la llengua dels seus avantpassats. Aquesta fidelitat lingüística del senyor Recasens i Collbató, d'altra banda tan encomiable, hagué de resultar decisiva —quines coses té la vida! - en la meva posterior relació amb en Rafel i, per descomptat, en les nostres carreres literàries." (43)

[in Narbonne, where his parents had moved when the war broke out and from where they returned in the mid 1940 s so that their children could be educated in direct contact with the language of their ancestors. Mr. Recasens i Collbató's linguistic fidelity, so praiseworthy in itself, turned out to be decisive - such is life! - in my later relationship with Rafel and, it goes without saying, in our literary careers.]

Through the competing artistic endeavors of the two friends and rivals, Riera dramatizes the linguistic and cultural tensions unleashed by the Spanish Civil War and their lingering aftermath in the years of the Franco dictatorship. Together the brother writers are two halves of a schizophrenic nation.

In Riera's allegorical plotting of literary culture and linguistic nationalism, the narrator's language is Spanish, since he is raised in the Spanish-speaking Catalunya of the winners. By telling the story of his indissoluble bond with Rafel, he subordinates Rafel's life to his own narrative purpose. While the dichotomy seems straightforward: Spanish surname-Spanish language, Catalan surname-Catalan language, Riera undermines the simple equation with the interwoven language of the two men. Despite Rafel's historical attachment to Catalan, he writes his first poems in French. The Spanish-speaking narrator translates this poetry into Catalan, the language in which they are published. In French, Rafel's verses are stale and unmarketable, as he confesses: "ningú no dóna un franc per ells. No interessen. Els meus poemes sonen a déjà $v u^{\prime \prime}$ [no one gives a franc for them. They have no interest. My poems sound like déjà vu] (s2). Despite his childhood in France, French is a second-hand language, not the language of his vivencias intimas. Through the narrator's translations

17 Late in the story the narrator's Spanish name appears when Rafel Recasens dedicates his book to him: "Al meu estimat amic, José Ignacio Díaz de Benjumea, mon semblable, mon frère" [To my dear friend] $(56)$. The fact that the narrator's family has property in the province of Tarragona (43), while Rafel Recasens's family is from Lleida (45), doubtless also contributes to their respective language formations. 
into Catalan, Rafel becomes a successful and admired Catalan author, but, if we are to believe the first-person narrator - always a risky business - Rafel's literary language, the language in which he publishes, is borrowed from his brother writer. In turn, the narrator's own efforts to write poetry directly in Catalan fail for lack of originality. He is a brilliant translator into Catalan, but a flawed creator in both Catalan and Spanish, the language in which he publishes his own poetry. His relationship to Catalan is vexed: "Vaig néixer a la literatura com a traductor d'una llengua que si no m'és desconeguda, tot al contrari, mai no he sentit com a pròpia i que, no obstant això, me pareix molt més idònia per a la poesia que el mateix castellà" [I started in literature as the translator of a language which, if it isn't completely unknown to me, in fact just the opposite, I have never felt to be my own and which, nevertheless, seems to me much better suited to poetry than Spanish itself] (46).

According to the narrator, when his friend Rafel Recasens tries to write in Catalan his verses are unimaginative - "exercicis escolars" [schoolboy exercises] (45), the narrator calls them- but in the narrator's Catalan translations Rafel's poetry strikes a brilliant note. Hence the irony: literary success depends on cultural and linguistic identity and in the case of Rafel's poetry that language is faked. Of course, the fact that the narrator is a failed poet is not unrelated to his devastating critique of Rafel's poetry in its original language, be it French or Catalan. Rafel insists that while the narrator is free to write in either language, he is not (47); his obligation, as Riera's Spanish translation clarifies, is to write in Catalan, to be faithful to his parents' language (Contra el amor 45). At the same time, Rafel urges the narrator to compose poems in Spanish, his "llengua familiar" [family language] (46), and to pay homage to his ancestor, Ramón de Campoamor, a popular but largely pedestrian Romantic poet. ${ }^{18}$ Even when Rafel tries again to write directly in Catalan, the narrator takes the credit for the verses:

els poemes d'en Rafel que havien d'integrar Aigua passada, apareguts el 1962, foren escrits directament en català amb versos manllevats, versos sobrers d'Extrarradios, llibre a la composició del qual assistí i sobre el qual opinà detingudament" (48).

[the poems by Rafel that comprised Aigua passada [Water over the Dam], which appeared in 1962, were written directly in Catalan with borrowed verses, castoff verses from Extrarradios [Outskirts], a book in whose composition he assisted and on which he carefully commented.]

Again, Riera's translation makes explicit Rafel's role in the 
publication of the narrator's book of poems, Extrarradios: "libro que él, naturalmente, se encargó de corregir antes de ir a la imprenta" [a book that he, naturally, took charge of correcting before it went to the printer] (Contra el amor 46). ${ }^{\text {I9 }}$ Thus, questions of narrative reliability aside, each man intervenes in the other's writing, rewriting the poems' original language, and each considers himself to have a profound understading of the other's family tongue. In the creative process leading to publication, neither man stands alone; the two halves of the cultural whole collaborate in the printed volume, although neither poet admits to what Mirella Servodidio characterizes as their "symbiosis" (442).

Riera further complicates the interconnection between the two men by doubling their artistic ambitions. Rafel becames a celebrated Catalan poet but lacks originality as a painter; success evades the narrator as a poet but he gains fame as a painter. The narrator expresses their interdependency, first in a painting that brings to mind Velázquez's "Las meninas," both in its use of the reflecting mirror and the artist's self representation: "el vaig pintar un parell de dies desprès davant d'un mirall en el qual també es reflectia el meu propi rostre pintant-Io" I painted him a few days later in front of a mirror in which my own face is also reflected as I paint him] (49). Mirroring each other, reflecting and inverting each other's experiences, the two form an inseparable whole. The tension that binds the brother artists finds its ultimate expression in the narrator's final poem, which problematizes language usage further:

Vaig escriure'l en castellà $i$ de seguida vaig traduir-lo al català. No sé quina estranya textura té aquesta llengua de botiguers, que diría en Rafel, perquè tot soni com acabat d'anomenar per primera vegada... Suposem que ni això no sigui veritat $\mathrm{i}$ que succeeixi una altra cosa, que jo sóc únicament capaç de crear un text ambigu, suggeridor, amb sentit de P'idioma, quan tradueixo. (58-59) II wrote it in Spanish and immediately I translated it into Catalan. I do not know what strange texture this language of shopkeepers, as Rafel would say, possesses, because everything sounds as if it had just been named for the first

\footnotetext{
"diglósico" [diglossic]. Writers like the poets José Agustin Goytisolo, Jaime Gil de Biedma y Carlos Barral, she says: "No son bilingües en el sentido de que su lengua de cultura es la castellana de modo muy clara... no se han planteado nunca ese problema [escoger una lengua sobre otra]" [They are not bilingual in the sense that their cultural language is very clearly Spanish... they have never faced that problem of choosing one language over another] (Nichols 217). Their generation, she adds, began to write in the early postwar years when Catalan was relegated to a domestic language used exclusively at home and hence not viable as a literary mode of expression. This is precisely the problem that her story explores through both the narrator and Rafel Recasens.

19 In the Catalan original Rafel's role is less explicit: "llibre a la composició del qual assistí i sobre el qual opinà detingudament" [a book during the writing of which he was present and about which he gave his opinions at great length] (Contra 48 ).
} 
time... Let us suppose that not even that is true and that something else happens, that I am only capable of creating an ambiguous, suggestive text, with a real sense of language, when I translate. ${ }^{20}$

In twinned ironies, translation becomes the truly creative act, as the Spanish-speaker narrator, not Rafel, exalts the poetic suppleness of Catalan. Thus, in the full expression of their shared poeric voice, the narrator supplants Rafel altogether, penning the original verses as well as their translation; then he gives Rafel the poem to publish under Rafel's own name. The game of authorship and the intricate overlay of identities confirm their intimate sameness, despite the struggle for power that is the flip side of brotherly love:

el subjecte poètic, desdoblant-se, passa revista a la seva identitat inventada, a les humiliacions a què sotmet el seu "adelfos", que, com ell, té la mateixa estatura, els mateixos ulls marronencs i potser, sense saber-ho, la mateixa tendència al vici nefand. (59).

[the poetic subject, splitting himself in two, reviews his invented identity, the humiliations to which he submits his "brother" who, like him has the same height, the same gray-brown eyes and perhaps, without knowing it, the same tendency towards the unspeakable vice.]

Published as Els miralls [Mirrors], ${ }^{21}$ the poem captures the mirror image of narrator and rival, "[r]eflectint-se al fons del mirall" [reflecting each other in the depths of the mirror] (59), fusing them into a single artistic expression: "nuestro mejor poema" [our best poem] (Contra el amor 56). ${ }^{22}$ They are, indeed, the two halves of post-war Catalunya's history, language, literature, and schizophrenic duality, a relationship of sameness and difference that is figured as well in Riera's story as the love that dares not speak its name.

In attempting to explain the two friends' singular linguistic echoing, Rafel specifies that, while they speak different languages, they

20 In her Spanish translation, Riera inserts into the narrator's lament about his flawed creacive capacity the phrase "con grandes dosis de ingenio ${ }^{n}$ [with large doses of genius] (Contra el amor 56). It is worth noting that Riera's Spanish versions of her fiction frequently reduce minor ambiguities by elaborating on rather than merely translating her own words.

2I The titles of the books of poetry encapsulate the story's linguistic play, and in the Catalan original Riera carefully retains the Spanish language titles of the narrator's books-Extrarradios, Sinfonía en gris menor (the latter becomes En las fances del viscoso animal in the Spanish translation). Rafel's books have Catalan titles ( 'ou $^{\prime}$ com balla, Aigua passada, Els miralls) in both versions. The intertextual play implicit in these titles merits further attention.

22 In contrast in the Catalan version of the story, the egotistical narrator refers to it as "el meu millor poema" [my best poem] (59), thus undermining the sense of collaboration. 
nevertheless share a mutual language, since they employ the same colloquial turns of phrase, as a result of their daily conversations (5657). Riera seems to be saying that, despite their differing codifications, the languages of Catalunya reflect a single cultural experience, the production of a unitary but bilingual culture. To capitalize on their linguistic diversity and interdependence - or rather, on the narrator's dual talents as translator and author- Rafel suggests writing "una novel.la bilingüe" [a bilingual novel]: "Ell ho faria en francès, que jo posteriorment traduiria, a més d'escriure també la meva part en castellà" [He would do his part in French, which I would later translate, in addition to also writing my part in Spanish] (57). The collaborative project anticipates the novel that another self-reflecting pair, Ángela and Miquel, compose in Qüestió d'amor propi. Ironies aside, the bilingualism proposed by Rafel is more precisely the refraction of a single text into its three component languages, again suggesting the fault lines marking the constitutive parts of Catalan national identity.

The duality within and between the male characters in "Mon semblable, mon frère" echoes a quotation from Empedocles that Riera has cited a number of times: "Yo era a la vegada arbre i ocell, al-lot i al-lota, peix mut dins la mar" II was at once tree and bird, boy and girl, a mute fish in the sea]. ${ }^{23}$ As Riera's has explained: "yo quería resumir el artista, es decir, el andrógino. Por eso decía que éramos dos cosas a la vez, y que la naturaleza y el arte son ambiguos por antonomasia" [I wanted to sum up the artist, that is, the androgyne. For that reason I said that we were two things at the same time, and that nature and art are ambiguity itself] (Nichols 2II). In "Mon semblable, mon frère" this ambiguity plays out not only in language and creative expression but in sexuality. At the height of their productivity, the elision of the two men's voices extends to their bodies in a probable (but for the narrator textually irreproducible) sexual embrace.

In a mise en abyme of the story's tension between linguistic identity and literary creation, Riera further probes the problematic nature of authorship. The narrator's wordplay on the phrase "les moltes plumes de La gaviota" [The Seagull's many quills] (46) signals the parallel between the novel and Rafel's poetry. Cecilia Böhl penned La gaviota originally in French; the editor José Joaquín de Mora translated and reworked it into Spanish before publishing it. ${ }^{24} \mathrm{By}$ facetiously addressing the narrator as "Mi querido José Joaquín" [My

23 Riera first uses the quote as the epigraph to "Te deix."

24 Riera's character Rafel parallels Cecilia Böhl in his linguistic diversity. Born in Switzerland to a Spanish mother and a German father, Böhl was educated in Germany, later lived in Spain and initially wrote her stories and novels in French. Since Rafel's first 
dear José Joaquín], Rafel acknowledges his friend's hand in his text on the model of the editor of La gaviota. When the narrator, in return, addresses Rafel as "Fernan," the masculine pseudonym used by Cecilia Böhl, he brings not only authorship but gender into the game. What exactly does a name hide: author, gender, language, nationality? The issue Riera raises has to do with both La gaviota and Rafel's poetry: What is the connection between translation and rewriting, between a translator/editor and an author? It is a question, as I have observed, to which she gives one answer in her own work, in which she both writes and translates/rewrites her fiction. In this sense, in her own creative activity she carries out the roles of both Cecilia Böhl and José Joaquín de Mora, of both the narrator, José Ignacio, and the poet, Rafel Recasens. On one level, it is Riera's own duality that "Mon semblable, mon frère" satirizes. On another, however, it is the linguistic tensions that underlie contemporary Catalan literature. It is also the matter of the relationship between life and writing, between being and creating, which, as we saw, also comes to the fore in Qüestió d'amor propi. The Barcelona-Madrid dichotomy dramatized in the Angela-Miquel affair is here displaced onto the mirrored Catalan identity of two brother authors as one body and one body politic. ${ }^{25}$ Each man exploits, dominates and inspires the other, but each tries to wrest the cultural capital for himself alone. ${ }^{26}$ The poem Els miralls fuses the writing of one with the fame of the other, melding them into an indissoluble whole, so that at very moment when the narrator faces a life-threatening illness, Rafel commits suicide. In the narrator's informe [report] (4I), he takes control of their story, writing both halves and laying claim to his share of Rafel's fame.

With Rafel Recasens dead and the narrator's role in his extraordinary success unacknowledged, the narrator takes control of the story of their artistic collaboration. The two voices, nationalities

literary language is French, while the language of his later education is Spanish, Catalan is as foreign to him as a language for literary expression as Spanish was to Böhl. Curiously, in the Spanish translation Riera eliminates a final phrase that clarifies her literary allusion: "les plomes de l'ocell mari i la família Böhl de Faber" [the feathers of the seabird and the Böhl de Faber family] (46). Perhaps she considers the reference more accessible to Spanish readers than to Catalan readers. A further connection between La Gaviota and Catalunya is worth noting as well: the eponymous protagonist, Maria Santaló, has a Catalan father.

25 In Bellver's reading, the story's intertextual echoes "suggest that writing is but a process of doubling, of duplication of other authors" (245), arguing that "only together could Rafel and José Joaquín produce publishable works" (246), She concludes that in the stories in Contra l'amor the double "becomes a malevolent, fraudulent, or artificial force that makes convergence problematic and the question of self-creation relevant" $(247)$.

26. This accords with Bourdieu's treatment of capital, including cultural capital, "simply as a resource (that is, a form of wealth) which yields power" (Calhoun 69). 
and bodies fully fuse into one: "En nom de tots dos tinc jo, amb raons suficients, la darrera paraula" [In the name of the two of us I have -with good reason- the last word.] (62). Rafel had observed this fusion much earlier, when the narrator painted their mirrored images: "Com si no fóssim més que una sola persona" ["As if we were only a single person"] (49). In their poetry and art, Spanish and Catalan voices and visions are inextricably intertwined. Rafel's Catalan is an oral language; it is a Spanish speaker who can give voice, second-hand, to truly remarkable Catalan verses. The "Catalan" poet wins recognition and fame, but ultimately the "Spanish" voice has control of their story. Riera here fleshes out her belief, quoted earlier, that language chooses us, that the only possible mode of expression is the language of one's inner self. In a further twist, the narrator tells his story in Catalan, thus subordinating the whole play of language and critique of cultural institutions to the dominant voice of the Catalan language. The narrator may, as he asserts, have ghostwritten Rafel's poetry, as Rafel inspired the narrator's pictorial masterpiece, but the only example of either artist's work comes to us in the form of the narrative we are reading. The story offers a probing satire of the state of Catalan culture, but the narrator's use of Catalan reinstates what his critique calls into question.

In this story, as in the novel Qüestió d'amor propi, Riera parodies the economics of literary success and the commodification of culture. Precisely because Rafel "writes" poetry in Catalan, he becomes a national icon, inserted into the pantheon of Catalan letters as testimony to the vitality and merit of the national culture. His first book, published in 1958 , "havia conegut dues edicions - un cas insòlit en poesia i més en aquell context de persecució lingüística i grisor lírica" [had gone through two editions - an unheard of event in poetry and more so in that context of linguistic persecution and lyrical grayness] (46). Through the narrator Riera plants the ambiguity of whether the climate of linguistic repression or a general lack of poetic inspiration creates the national conditions in which Rafel's poetry stands out, or whether the two factors are inseparable. Extending her satire, Riera has Rafel receive the ultimate accolade for a poet: students study his work alongside that of the great Catalan poets Ausiàs March and Salvador Espriu (48). As the historian Michael Keating reminds us, "[m]inistries of culture or the arts have a particular responsibility to promote national culture, whether at home or abroad" (29). For Riera, the excesses of this cultural promotion is fertile ground for parody. Even Spanish cultural institutions pick up on the elevation of Rafel as the Catalan national poet, seeing in his writing an act of poetic vindication of Catalan: 
Per primera vegada les revistes literàries castellanes... es feien eco d'un jove autor que escrivia en un idioma encara humiliat, ofès i maltractat. En algunes ressenyes, a més, Recasens era valorat per sobre de Salvador Espriu. (56)

[For the first time Spanish literary magazines... echoed the word about a young author who was writing in a language that was still humbled, insulted and ill-treated. In some reviews, in addition, Rafel Recasens was valued above Salvador Espriu.]

By placing Rafel's poetry alongside that of his canonical forefathers, Riera seems to share Teresa Vilarós's caveat that " Catalan identity' may quickly become a commodity, an ideological simulacrum that can function strategically and seductively to 'sell' or 'negotiate' Catalan cultural capital profitably" (4I). Riera casts doubt on the cultural enterprise that makes "cultural capital" of Rafel by questioning the authenticity of the individual poetic voice that speaks for Catalan culture.

Riera's irony is unmistakable: the new poet displaces canonical authors in a culture that requires constant signs of contemporary cultural vitality and hence values new artefacts over old ones. ${ }^{27}$ Rafel's consecration as a national figure emblematizes the equation of language and nation. At his death, "havia estat enterrat amb tots els honors de poeta nacional. En aquestes alçades era un exemple inqüestionable per al recobrament de la llengua pàtria" the had been buried with all the honors of a national poet. At this stage he was an indisputable example of the recovery of the nation's language] (60). The symbiotic duality of authorship recorded by the narrator makes "the recovery of the nation's language" both a farcical misstatement of fact and a truth of Catalan culture. Both readings are further destabilized by the narrator's unreliability. In Rafel Recassens's poetry the "nation's language" is an admixture of French, Catalan, and Spanish that resolves itself, through translation, in an artificially autonomous, language.

Riera is harshest in her critique of the institutions that shape the cultural economy. She resists the institutional impulse to collapse linguistic diversity into univocity. This cultural marketing of the Catalan language leads to the false assumption by those outside Catalunya that the nation is unified by language, as a recent article notes: "Desde Madrid se cree, en ocasiones, que en Barcelona sólo se escribe o

27 Riera's satire of literary culture takes on the culture of literary prizes as well: "Rafel va obtenir el premi de la Crítica, La Lletra d'or, i tots els guardons que aquell any s'atorgaren a Catalunya foren pel seu brevíssim poemari: 235 versos, el títol del qual, Els miralls, únicament, era de collita prôpia" (60). '[Rafel received the Critics' award, the Golden Letter, and all the prizes that were awarded in Catalunya that year went to his very slim book of poetry: 235 versos whose title, Mirrors, was his only contribution]. 
publica en catalán" [From Madrid the perception is, at times, that in Barcelona one only writes and publishes in Catalan] (V.). ${ }^{28}$ Riera's mistrust of institutional authority, allegorization of the cultural politics of publishing and her denunciation of the author as icon reach their culmination in "Mon semblable, mon frère." In this story, as in "Joc de miralls" and Qüestio d'amor propi, the dynamics of gender (self and other) and the dynamics of language (Catalan and Spanish) deconstruct national identity and canonical national culture. Language and nationality, like the sexes in gender conflict, mirror, devour, and depend on the other, in a kind of cultural schizophrenia.

\section{MARYELLEN BIEDER INDIANA UNIVERSITY}

\section{WORKS CITED}

AguAdo, Neus. "Epístolas de mar y de sol: Entrevista con Carme Riera." Quimera No. IOS (1991): 32-37.

Bellver, Catherine. "Convergence and Disjunction: Doubling in the Fiction of Carme Riera." Moveable Margins. $23 \mathrm{I}-49$.

Elorza, Antonio. "Becoming Normal: Cultural Production and Cultural Policy in Catalonia." Spanish Cultural Studies: An Introduction. Ed. Helen Graham and Jo Labanyi. Oxford: Oxford UP, $1995 \cdot 342-46$.

Epps, Brad. "A Writing of One's Own: Carme Riera's Qü̈estió d'amor propi." Moveable Margins. 104-52.

FARriNGTON, Pat. "Interviews with Ana María Matute and Carme Riera." Tesserae: Journal of Iberian and Latin American Studies 6 (2000): $81-89$.

GlenN, Kathleen M. "Conversation with Carme Riera." Catalan Review 8 (1994): 203-09.

—. Mirella Servodidio and Mary S. Vásquez. Moveable Margins: The

28 Valenti Puig adds a comment that reinforces the thrust of Riera's story: "Aquellos que escriben en castellano desde Cataluña se pueden sentir rechazados por la cultural oficial catalanista. A la inversa ocurte igual. Finalmente, los que somos bilingües no somos ni carne ni pescado" [Those who write in Spanish in Catalunya can feel rejected by the official pro-Catalan culture. The obverse also happens. Finally, those of us who are bilingual are neither fish nor fowl] (V.).

Riera's ironic appreciation of linguistic sameness and difference surfaces in her observation that the poets on whom she drew for her story, Gabriel Ferrater and Jaime Gil de Biedma, "tuvieron la enorme suerte de escribir cada uno en una lengua distinta, porque si no, hubieran sido el mismo poeta" (Farrington 89). 
Narrative Art of Carme Riera. Lewisburg: Bucknell UP, 1999. Keating, Michael. Nations against the State: The New Politics of Nationalism in Quebec, Catalonia and Scotland. New York: St. Martin's P, 1996.

LABANYI, Jo. "Postmodernism and the Problem of Cultural Identity." Ed. Helen Graham and Jo Labanyi. Spanish Cultural Studies: An Intraduction. Oxford: Oxford UP, 1995. 396-406,

MÉRIDA-JIMÉNEZ, Rafael M. "La nueva Barcelona finisecular:

Rupturas y fidelidades de una antología bilingüe." Letras Peninsulares I2.I (Spring 1999): 142-5I.

Nichols, Geraldine C. Escribir, espacio propio: Laforet, Matute, Moix, Tusquets, Riera y Roig por si mismas. Minneapolis: Institute for the Study of Ideologies and Literature, 1989.

- "'Mitja poma, mitja taronja": génesis y destino literarios de la catalana contemporánea." Anthropos 61-62 (1986): 118-25.

Riera, Carme. Contra el amor en compañia. Barcelona: Destino, 199i.

- Contra l'amor en companyía. Barcelona: Destino, 1991.

—. Cuestión de amor propio. Barcelona: Tusquets,1987.

." I Leave You, My Love, the Sea as a Token." Trans. Alberto Moreiras. On Our Own Behalf: Women's Tales from Catalonia. Ed. Kathleen McNerney, Lincoln; U Nebraska P, 1988. 3t-45.

- Joc de miralls. Barcelona: Planeta, 1989.

- Mirror Images. Trans. Cristina de la Torre. New York: Peter Lang, 1993 .

- Palabra de mujer. [Trans. of Te deix, amor and Jo pos per testimoni.] Barcelona: Laia, 1980.

Por persona interpuesta. [Trans. of Joc de miralls.] Barcelona: Planeta, 1989 .

- Qüestió d'amor propi. Barcelona: Laia, 1987.

Te deix, amor, la mar com a penyora. Barcelona: Laia, 1975.

- Te dejo, amor, el mar en prenda. Trans. Luisa Cotoner. Madrid: Espasa-Calpe, 1991.

SERVODIDIO, Mirella. "Surfing the Internet with Borges and Carme Riera." Revista Hispánica Moderna 49 (1996): 434-45.

STEWART, Miranda. "Language and National Identity." Encyclopedia of Contemporary Spanish Culture. Ed. Eamonn Rodgers. London: Routledge, 1999 .

TsUCHIYA, Akiko. "The Paradox of Narrative Seduction in Carme Riera's Cuestión de amor propio." Hispania 75 (1992): 281-86.

V., M. A. "Autores catalanes establecen un puente cultural con Madrid." El País 9 mayo 2000.

Valis, Noël. "True Confessions: Carme Riera's Cuestión de amor propio." Revista Canadiense de Estudios Hispánicos 23, No. 2 (Winter 1999): 3II-28. 
VÁZqueZ Montalbán, Manuel. La literatura en la construcción de la ciudad democrática. Barcelona:Crítica, 1998.

VILARós, Teresa M. "A Cultural Mapping of Catalunya." The Cambridge Companion to Modern Spanish Culture. Ed. David T. Gies. Cambridge: Cambridge UP, 1999-37-53. 